\title{
FACTORS HINDERING ECOINNOVATIVENESS OF PAPER INDUSTRY COMPANIES IN POLAND
}

Summary: Implementation of eco-innovations within a company is a process which should be preceded by thorough analysis of factors conditioning eco-innovativeness which is connected most of all with considerably high level of complexity of this process. The hereby article focuses on the analysis of factors conditioning the implementation of eco-innovations with special consideration of the factors hindering eco-innovativeness. Theoretical deliberations have been supported by research conducted amongst businesses operating in the paper industry in the territory of Poland.

Kerw ords: eco-innovation; factors conditioning eco-innovativeness of companies.

Klasyfikacja JEL: D22.

\section{INTRODUCTION}

The implementation of eco-innovations in the current market conditions constitutes one of the solutions allowing businesses to gain competitive advantage on the market. Through the implementation of eco-innovations businesses not only create the reality that surrounds them but they also fit within the new paradigms of conducting business activity such as corporate social responsibility or the sustainable development. The eco-innovations

* Adres do korespondencji: Edyta Bochenek, Szkoła Główna Handlowa w Warszawie, al. Niepodległości 128,02-554 Warszawa, e-mail: e.bochenek@boxpol.eu. 
implementation process requires the coordination of numerous elements hence it constitutes a considerable challenge for the company. In order to implement eco-innovations effectively and efficiently in the company it is necessary to identify the factors which determine the eco-innovativeness of businesses as the lack of information on the possessed resources and the conditions of the surroundings may determine their failure.

Business entities as elements constituting market economy operate and make their economic decisions in the surroundings of the other market participants. One of such decisions is the implementation of eco-innovations which is conditioned by the external factors located in the surroundings of the company. Additionally, companies themselves generate a number of internal factors influencing the level of absorption of the ecological innovations such as the size of the entity, its employment structure, financial situation of the company and many others [Carillo-Hermosilla, Del Rio González, Könnölä, 2009, p. 33]. Therefore the objective of the hereby article is the identification of the determinants influencing the eco-innovativeness of companies on the basis of the research conducted among the entities operating in the field of paper industry in Poland. In the empiric research the focus was placed among others on the determination of factors hindering eco-innovativeness mainly due to the low level of development of ecoinnovations within the said industry and the increasing interest in environmental protection.

\section{CHARACTERISTICS OF FACTORS CONDITIONING THE IMPLEMENTATION OF ECOINNOVATION IN THE COMPANY}

The most common division of factors conditioning the implementation of eco-innovations is the one distinguishing external and internal factors [Kemp, Volpi, 2008, p. 14] but the specialist literature provides multiple more extensive classifications. Due to the fact that the eco-innovations implementation process is difficult and multi-aspectual it seems justified to analyse the largest possible number of factors which may influence the effective implementation of eco-innovations in the company.

One of the division presented in the specialist literature is the one created by P. del Rio González which lists the following factors among the determinants of company's eco-innovativeness [Del Rio González, 2009, pp. 861-863]: 
- internal factors;

- external factors;

- factors related to ecological technology.

Among the internal factors the author has classified those directly related to the company such as the size of the company, its structure of ownership, financial and technological capability. The external factors on the other hand include those factors only indirectly dependent on the business entity such as the structure of the given industry, the structure of the market on which the company operates as well as the institutional surroundings of the entity in question. The last category of determinants includes the factors directly related to eco-innovations and all the problems connected with the compatibility of eco-innovation with the existing technological systems [Carillo-Hermosilla, Del Rio González, Könnölä, 2009, pp. 46-50]. The classification proposed by P. del Rio González has been subsequently considerably extended in the later works by the same author and the detailed division and characteristics of determinants have been presented in table number 1.

When interpreting the factors determining the eco-innovativeness of companies N.A. Ashford directs our attention above all to the fact that to be able to speak about eco-innovations we need to be dealing with technological innovations and for such innovations to appear within a company the occurrence of the following factors is necessary [Ashford, 2005, pp. 159-164].

- willingness to change (the attitude of managers and owners of the entity to changes);

- feasibility/motivation of change (technological possibilities, exploitation of technological gap);

- ability to change (training of personnel, attitude of organisation to changes).

What is worth emphasising the author in course of characterisation of the drivers influencing the implementation of eco-innovations lists neither the technological possibilities nor financial capability as the most important ones but the aspects completely unburdened by the financial costs namely the willingness to change. It remains a fact that the author decisively stresses the fact that he identifies eco-innovations with technological innovations which undoubtedly entails the assumption that a given entity possesses the technical capability to introduce the changes yet the possessed technology does not necessarily create possibilities to conduct alterations. The indication of the enormous need for proecological educational is also meaningful as the basic element determining the implementation of eco- 
-innovations is constituted by the attitude of those managing the company to the said change.

Table no 1. Division of drivers influencing the implementation of eco-innovations in companies

\begin{tabular}{|c|c|}
\hline Drivers of eco-innovation & Characteristic \\
\hline $\begin{array}{l}\text { internal factors affecting devel- } \\
\text { opment and adoption of eco- } \\
\text { innovation }\end{array}$ & $\begin{array}{l}\text { 1) characteristics of the company } \\
\text { - financial situation } \\
\text { - size of the company } \\
\text { - position in the value chain } \\
\text { - age of the company } \\
\text { - multinational or local character of the company } \\
\text { - export-oriented production } \\
\text { - characteristics of the sector } \\
\text { 2) technological competency } \\
\text { 3) environmental strategy } \\
\text { 4) organizational factors } \\
\text { 5) attitude of managers towards change } \\
\text { 6) attitude of employees towards change }\end{array}$ \\
\hline $\begin{array}{l}\text { external factors affecting deve- } \\
\text { lopment and adoption of eco- } \\
\text {-innovation }\end{array}$ & $\begin{array}{l}\text { 1) public policy } \\
\text { 2) the general situation of the company } \\
\text { 3) lack of information } \\
\text { 4) suppliers } \\
\text { 5) final consumer, industrial clients, public custo- } \\
\text { mers } \\
\text { 6) competitors } \\
\text { 7) industrial associations } \\
\text { 8) environmental non government organisations } \\
\text { 9) research centers } \\
\text { 10) financial institutions }\end{array}$ \\
\hline $\begin{array}{l}\text { characteristics of the technolo- } \\
\text { gies }\end{array}$ & $\begin{array}{l}\text { 1) cost and cost savings } \\
\text { 2) potential benefits } \\
\text { 3) complexity of eco-innovation } \\
\text { 4) compability with existing system } \\
\text { 5) existence of an installed base } \\
\text { 6) complementary innovations } \\
\text { 7) sectoral technological opportunities } \\
\text { 8) expectations of cost reductions and quality } \\
\text { improvements }\end{array}$ \\
\hline
\end{tabular}

Source: own materials based on J. Carillo-Hermosilla, P. del Rio González, T. Könnölä, Eco-innovation When Sustainability And Competitiveness Shake Hands, Palgrave Macmillan, New York, 2009, pp. 32-50. 
Another division of drivers determining the eco-innovativeness of business entities is characteristic for numerous authors and it refers to the demand and supply factors which include [Kesidou, Demirel, 2012, pp. 862864; Horbach, Rammer, Rennings, 2012, pp. 112-114]:

1) regulations and legal acts of the given country related to the environmental issues policy:

- implementation of regulations concerning environmental protection,

- current and future legislative solutions concerning environmental protection.

2) supply determinants:

- reduction of costs,

- increase of efficiency,

- organisational innovations: environment oriented management systems, prolonged producer's responsibility,

- research and development,

- relations between the entities, pressure from suppliers.

3) demand determinants:

- customer awareness concerning environmentally friendly products,

- expectation to increase market share,

- gaining new markets.

Authors defining determinants constituting the implementation of ecoinnovations apart from the demand and supply factors pay considerable attention to the factors related to the legal regulations binding within the territory of the given country. There exists a perfectly good reason why these factors have been listed first as the law beneficial for proecological solutions provides a very positive influence onto the development of ecoinnovativeness in the given country. Similarly government programmes enhancing the use of environmentally friendly solutions are also important. Such programmes apart from substantial assistance are frequently connected with measurable support for such initiatives, hence the important role of the government or of local and regional authorities in promoting proecological behaviours. On the other hand legal regulations oblige business entities to implement ecological solutions - otherwise businesses are forced to incur costs for the sake of the state for polluting the environment.

The most extensive classification of the factors determining the eco-innovativeness of companies was proposed by A. Pereira, X. Vence [Pereira, Vence, 2012, p. 80] and the results of their research have been presented systematically in table number 2 . 
Table no 2. Factors determining the implementation of eco-innovation in a company

\begin{tabular}{|c|c|c|}
\hline \multicolumn{2}{|c|}{ Type of determinant } & Factor \\
\hline \multirow{3}{*}{$\begin{array}{l}\text { conventional } \\
\text { factor }\end{array}$} & $\begin{array}{l}\text { structural characteri- } \\
\text { stics of the company }\end{array}$ & $\begin{array}{l}\text { - size } \\
\text { - sector } \\
\text { - age }\end{array}$ \\
\hline & business logic & $\begin{array}{l}\text { - cost savings } \\
\text { - customer's requirements } \\
\text { - customer's benefits } \\
\text { - customer's satisfaction } \\
\text { - expected demand } \\
\text { - export oriented strategy }\end{array}$ \\
\hline & $\begin{array}{l}\text { technological compe- } \\
\text { tence }\end{array}$ & $\begin{array}{l}\text { - R\&D activities } \\
\text { - path dependencies: innovation in the } \\
\text { past } \\
\text { - employees qualifications } \\
\text { - cooperation and network activities } \\
\text { - industrial relationship }\end{array}$ \\
\hline \multicolumn{2}{|c|}{ company's environmental strategy } & $\begin{array}{l}\text { - environmental innovation system } \\
\text { (ISO,EMAS) } \\
\text { - environmental criteria in product plan- } \\
\text { ning and development } \\
\text { - life cycle assessment activities of own } \\
\text { products } \\
\text { - waste disposal or take back systems } \\
\text { of own product } \\
\text { - environmental research on green } \\
\text { products } \\
\text { - informing the customers }\end{array}$ \\
\hline
\end{tabular}

Source: A. Pereira, X. Vence, Key business factors for eco-innovation:an overview of recent firm-level empirical studies, Cuaderno de Gestion Vol. 12 Especial Innovacion, Santiago de Compostella, 2012, p. 80.

To conclude the considerations concerning the determinants conditioning eco-innovativeness of business entities we may draw a conclusion that the basic factors which considerably influence the absorption of ecological innovation within the companies include the following:

- legal regulations,

- national, regional and local programmes supporting the proecological behaviours, 
- financial capabilities of the company,

- conducting research and development activities,

- technological capability of the company,

- willingness of the management personnel to implement eco-innovations,

- requirements of consumers.

The factors mentioned above obviously do not constitute the only factors conditioning the implementation of eco-innovations still they seem to be the most crucial ones. Alongside the factors mentioned before one more aspect should be stressed - namely the ecological awareness of the society which in Poland is unfortunately truly low. In the contemporary world dominated by the cult of money and orientation on profit members of society do not include the issues related to environmental protection within the scope of their interests. In common understanding the issue of environmental protection even though noticed, is not taken into consideration in the process of creation of development strategies mainly due to the high costs of implementation of proecological solutions and the limited knowledge of the subject. Additionally, consumers themselves more frequently take into consideration the economic factors rather than ecological ones when making their consumer choices. Only the change of the awareness of both entrepreneurs and consumers may positively influence the development of eco-innovativeness of business entities which shall perceive ecoinnovations as the chance to gain competitive advantage and become economically successful.

\section{FACTORS HINDERING ECOINNOVATIVENESS IN THE COMPANIES OF PAPER INDUSTRY - RESULTS OF EMPRIRIC RESEARCH}

The classifications of determinants conditioning the implementation of eco-innovations occurring in literature have served as the starting point for the performance of research in the scope of identification of factors which hinder the eco-innovativeness of entities operating in the field of paper industry in Poland. The companies included in the research belong to the paper industry which constitutes a part of processing industry within section $\mathrm{C}$ according to the Polish Classification of Business Activities and it belongs to division 17 that is production of paper and paper products. The detailed 
classification of individual groups, classes and subclasses has been presented in table number 3 .

Table no 3. Paper industry according to the Polish Classification of Business Activities

\begin{tabular}{|c|c|c|c|c|}
\hline \multicolumn{5}{|c|}{$\begin{array}{c}\text { SECTION C } \\
\text { PROCESSING INDUSTRY }\end{array}$} \\
\hline $\begin{array}{l}\text { SEC- } \\
\text { TION }\end{array}$ & GROUP & CLASS & SUBCALSS & NAME OF GROUPING \\
\hline \multirow[t]{10}{*}{17} & & & & $\begin{array}{l}\text { PRODUCTION OF PAPAER AND PAPER } \\
\text { PRODUCTS }\end{array}$ \\
\hline & 17.1 & & & $\begin{array}{l}\text { PRODUCTION OF PULP, PAPER AND } \\
\text { CARDBOARD }\end{array}$ \\
\hline & & 17.11 & 17.11.Z & PRODUCTION OF PULP \\
\hline & & 17.12 & $17.12 . Z$ & $\begin{array}{l}\text { PRODUCTION OF PAPER AND CARD- } \\
\text { BOARD }\end{array}$ \\
\hline & 17.2 & & & $\begin{array}{l}\text { PRODUCTION OF PAPER AND CARDBO- } \\
\text { ARD PRODUCTS }\end{array}$ \\
\hline & & 17.21 & $17.21 . Z$ & $\begin{array}{l}\text { PRODUCTION OF CORRUGATED PAPER } \\
\text { AND CARRDBPARD AND OF PAPAER } \\
\text { AND CARDBOARD PACKAGING }\end{array}$ \\
\hline & & 17.22 & 17.22 .2 & $\begin{array}{l}\text { PRODUCTION OF HOUSEHOLD GOODS, } \\
\text { TOILET AND SANITARY PRODUCTS }\end{array}$ \\
\hline & & 17.23 & $17.23 . Z$ & PRODUCTION OF STATIONERY \\
\hline & & 17.24 & 17.24 .2 & PRODUCTION OF WALLPAPAERS \\
\hline & & 17.29 & 17.29 .2 & $\begin{array}{l}\text { PRODUCTION OF OTHER PAPER AND } \\
\text { CARDBOARD PRODUCTS }\end{array}$ \\
\hline
\end{tabular}

Source: own materials based upon the information available at Main Statistic Office website http://stat.gov.pl/klasyfikacje

Paper industry has been selected for the research due to the fact that it constitutes an important sector of national economy and also because of the continuous development of the said industry. Observing paper industry over decades we may notice the large extent to which the civilisation progress and innovativeness influence changes occurring within the scope 
of production, products and also within the area of management of companies of this field and new marketing solutions. On one hand the civilisation development and technological progress have determined the dramatic fall of newspaper paper production, on the other the considerable increase in production of paper for the manufacturing of cardboard, packaging and hygienic articles. Table number 4 presents data concerning the volume of production expressed in thousands of tonnes of main products of paper industry over the period of 5 subsequent years.

Table no 4. Basic information of the production of industrial products - paper and cardboard

\begin{tabular}{|c|c|c|c|c|c|}
\hline & 2009 & 2010 & 2011 & 2012 & 2013 \\
\hline $\begin{array}{l}\text { Wooden cellulose sodium or } \\
\text { sulphate pulp other than for } \\
\text { chemical processing }\end{array}$ & 826.3 & 881.0 & 894.3 & 847.6 & 881.3 \\
\hline $\begin{array}{l}\text { mechanical and semichemical } \\
\text { pulps, pulps from other } \\
\text { cellulose raw materials }\end{array}$ & 318.9 & 298.8 & 307.4 & 303.9 & 305.8 \\
\hline paper and cardboard & 3275.0 & 3699.8 & 3755.6 & 3821.8 & 4105.5 \\
\hline $\begin{array}{l}\text { newspaper paper in rolls } \\
\text { or sheets }\end{array}$ & 166.3 & 149.0 & 148.7 & 149.4 & 141.7 \\
\hline corrugated cardboard & 1248.7 & 1324.1 & 1527.6 & 1587.6 & 1702.5 \\
\hline paper sacks and bags & 125.5 & 123.7 & 125.8 & 114.7 & 112.6 \\
\hline $\begin{array}{l}\text { cartons ad boxes from paper } \\
\text { and cardboard }\end{array}$ & 1521.9 & 1666.4 & 1746.6 & 1863.0 & 1980.7 \\
\hline toilet paper & 259.1 & 255.3 & 267.6 & 297.2 & 298.0 \\
\hline $\begin{array}{l}\text { towels from paper mass, } \\
\text { paper, cellulose wool or bands } \\
\text { of cellulose fibres }\end{array}$ & 141.5 & 142.8 & 166 & 214.4 & 201.9 \\
\hline
\end{tabular}

Source: own materials based on the publication of the Main Statistical Office - Industrial production in 2013, Main Statistical Office, Warszawa 2014.

On the basis of table no 4 we may conclude that over the period of the five subsequent years starting from 2009 until 2013 the production of the majority of products of paper industry has been growing successively. The largest increase was observed by the producers of corrugated cardbo- 
ard and carton and cardboard boxes. The considerable growth in the production of paper mass and cellulose wool towels over the period of four subsequent years and the later slight fall in 2013 are also meaningful, yet it does not alter the general increasing trend in the production of this type, which is influenced above all by the economic growth but also by the improving standard of living [Z̈ubrzak, 2014, p. 125].

Small, medium-sized and large companies have been selected for the survey with the exception of micro-companies therefore the group of businesses to whom the surveys were directed included 710 companies. The total number of 120 surveys have been returned, and all of those have proven to be properly filled in. The survey contained 20 questions out of which only two have been used for the hereby article, namely those regarding the factors hindering the implementation of eco-innovations in companies.

In case of the question concerning the external factors hindering the implementation of eco-innovations within the company emphasis was placed mostly on the factors connected with the state policy in the context of supporting eco-innovativeness of companies in market conditions. The structure of provided answers is shown in the diagram number 1.

In case of external factors hindering the eco-innovativeness of businesses operating in the paper industry the most important ones proved to be: lack of support from the state (20.30\% of all respondents), lack of clarity of legal regulations ( $15.45 \%$ of all respondents) and the lack of pro-innovation state policy (15.15\% of all respondents). Thus the main barrier for eco-innovativeness among Polish businesses of paper industry was shown to be the state policy which corresponds to the research into the eco-innovativeness of companies conducted worldwide [Del Rio González, 2005, 20-37; Frondel, Horbach, Rennings, 2007, pp. 572-584; Horbach, 2008, p. 172]. This thesis is additionally confirmed by the fact that none of the examined entities has indicated to any other barrier hindering the implementation of ecological innovations apart from those listed before. Moreover, among small entities the factors connected with the market situation proved to be important in terms of hindering eco-innovativeness whereas the large entities have failed to mention these issues altogether.

In the group of internal factors hindering eco-innovativeness special attention was paid to the factors related to financial aspects and also to those defining the attitude of entrepreneurs to eco-innovations. The structure of provided answers has been presented in graph number 2 . 


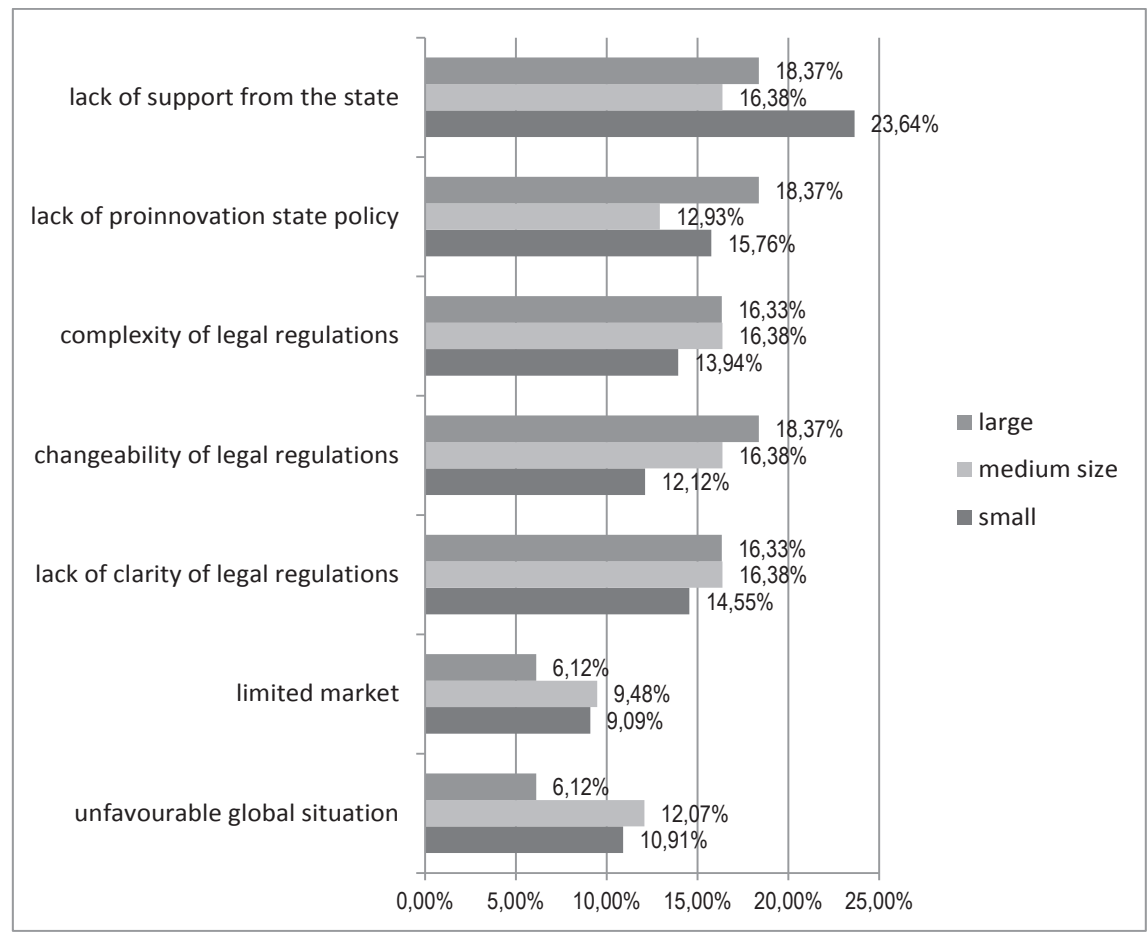

Diagram no 1. External factors hindering eco-innovativeness of entities operating in paper industry with the size of employment taken into consideration

Source: own materials.

The most important factors hindering the implementation of eco-innovations within the company include: high costs of eco-innovation $(22.86 \%$ of all respondents), lack of own free financial resources (19.37\% of all respondents) and the high risk of implementation of eco-innovation $(13.65 \%$ of all respondents).

The conducted research and obtained results prove the fact that the most important factors hindering eco-innovativeness are the financial aspects. Small businesses decisively point to lack of free own resources as the most crucial factor, while the medium-size and large ones in spite of the fact that lack of free own financial resources does not constitute a barrier for eco-innovativeness hint at high costs of eco-innovations and high risk connected with the implementation of eco-innovation, which directly influence the financial situation of the given entity. 
Graph no. 2. Internal factors hindering eco-innovativeness of entities operating in paper industry considering the size of employment

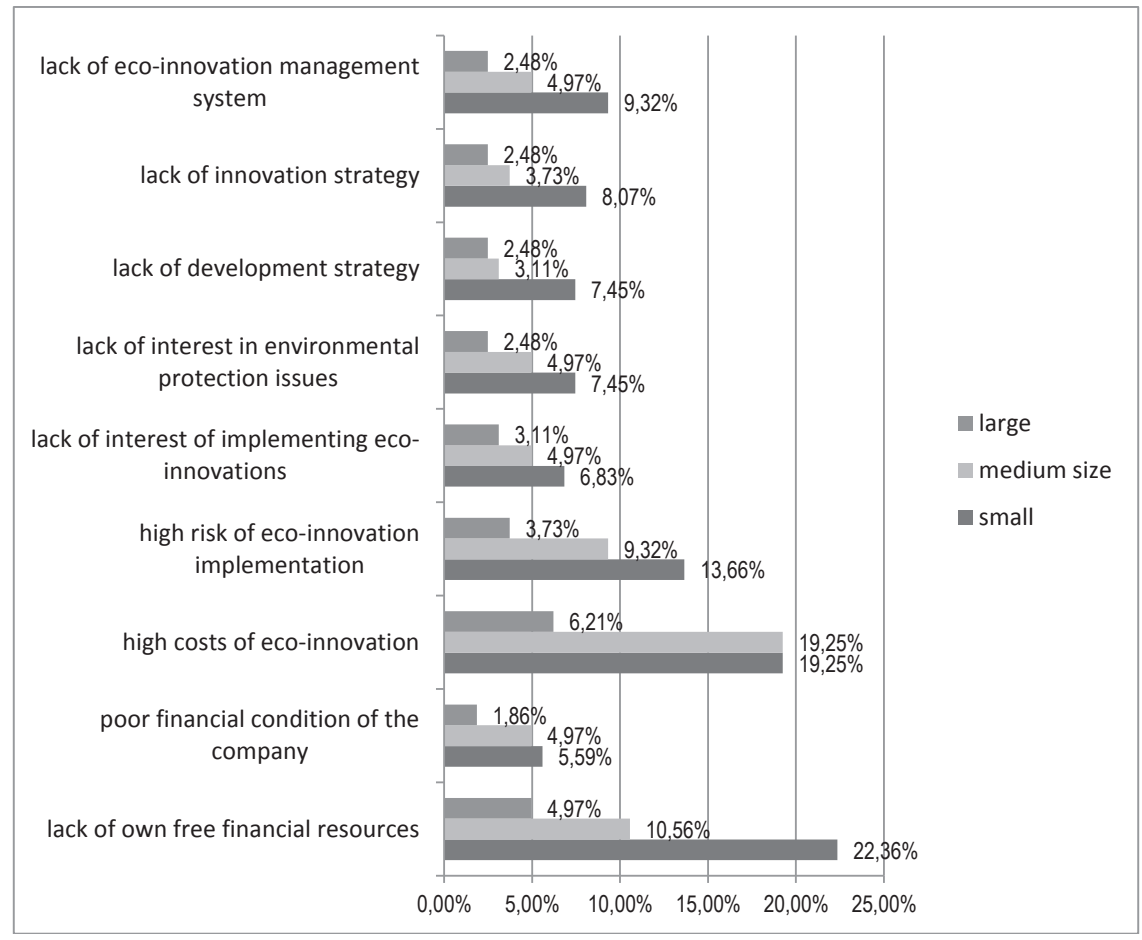

Source: own materials.

\section{SUMMARY}

Over the last decade the technological progress has led to increasing growth of production which resulted in ever larger problems related to environmental pollution. The considerable growth of consumption has led to the situation in which the exploitation of products and resulting post exploitation waste create a continuously growing series of threats for the environment [Adamczyk, 2004, p. 7]. In connection with the above mentioned the regulations concerning environmental protection change, care for environment is increasing and also the trend of conscious selection based on environmentally friendly ideas is more and more frequently propagated among consumers. All these factors lead to the fact that the influence onto the en- 
vironment is becoming an essential element of companies' strategies, which may be realised thanks to the implementation of eco-innovations.

Due to its pioneer character the implementation of eco-innovation within a company is a complex process, hence the realisation of this process should be preceded by a detailed analysis of the factors determining eco-innovativeness. Special attention should be paid to the aspects hindering eco-innovativeness as these very factors are mostly responsible for the effectiveness of the implementation process. It is also vital to conduct the identification of those negative factors in a comprehensive manner as in numerous cases they are mutually interwoven, some result from the others or they are in a smaller or larger extent correlated [Carillo-Hermosilla, Del Rio González, Könnölä, 2010, pp. 543-544].

The presented results of empiric tests conducted among business entities operating in paper industry indicate which factors hinder the implementation of eco-innovations the most. Among the external factors those connected with the state policy in the scope of legal regulations and pro-innovation state policy have proven to be the most unfavourable. On the other hand among the internal barriers mainly the financial aspect of eco-innovations implementation has been listed and the most frequently mentioned factors include: lack of own free financial resources and high costs of implementation of ecoinnovations. This confirms that the obtained results are similar to the results of research into eco-innovativeness of businesses conducted worldwide.

\section{LITERATURE}

Adamczyk W. (2004), Ekologia wyrobów, Polskie Wydawnictwo Ekonomiczne, Warszawa.

Ashford N. A. (2005), Government and Environmental Innovation in Europe and South Africa, [w:] Weber M., Hemmelskamp J., Towards Environmental Innovation Systems, Springer, Berlin - Heidelberg.

Carillo-Hermosilla J., Del Rio González P., Könnölä T. (2010), Policy Strategies to Promote Eco-Innovation, "Journal of Industry Ecology", Vol. 14, No 4.

Carillo-Hermosilla J., Del Rio González P., Könnölä T. (2009), Eco-innovation When Sustainability And Competitiveness Shake Hands, Palgrave Macmillan, New York.

Del Rio González P. (2005), Analyzing the factors influencing clean technology adoption: a study of the spanish pulp and paper industry, "Business Strategy and the Environment", Vol. 14. 
Del Rio González P. (2009), The empirical analysis of the determinants for environmental technological change: A research agenda, "Ecological Economics", Vol. 68 (3).

Frondel M., Horbach J., Rennings K. (2009), End-of-pipe or cleaner production? An empirical comparison of environmental decisions across OECD countries, "Business Strategy and the Environment", Vol. 16 (8).

Horbach J., Rammer Ch., Rennings K. (2012), Determinants of eco-innovation by type of environmental impact - The role of regulatory push/pull, technology push and market pull, "Ecological Economics", Vol. 78, Elsevier.

Horbach J. (2008), Determinants of environmental innovation - new evidence from German panel data sources, "Research Policy", Vol. 37 (1).

Kemp R., Volpi M. (2008), The diffusion of clean technology: a review with suggestions for future diffusion analysis, "Journal of Cleaner Production", Vol. 16, S1.

Kesidou E., Demirel P. (2012), On the drivers of eco-innovation: Empirical evidence from the UK, "Research Policy", Vol. 41, Elsevier.

Pereira A., Vence X. (2012), Key business factors for eco-innovation:an overview of recent firm-level empirical studies, "Cuaderno de Gestion", Vol. 12, Especial Innovacion, Santiago de Compostella.

Produkcja wyrobów przemystowych w 2013 r. (2013), Główny Urząd Statystyczny, Warszawa.

Żubrzak M. (2014), Światowy rynek wyrobów higienicznych, „Przegląd Papierniczy", 3/2014, Wydawnictwo SIGMA-NOT Sp. z o.o., Warszawa.

http://stat.gov.pl/klasyfikacje [01.05.2015]

\section{CZYNNIKI NIESPRZYJAJĄCE EKOINNOWACYJNOŚCI PRZEDSIĘBIORSTW BRANŻY PAPIERNICZEJ W POLSCE}

Streszczenie: Implementacja ekoinnowacji w przedsiębiorstwie to proces, który powinien być poprzedzony wnikliwą analizą czynników warunkujących ekoinnowacyjność, co wiąże się przede wszystkim z bardzo dużym stopniem skomplikowania tego procesu. Niniejszy artykuł koncentruje się na przeanalizowaniu czynników warunkujących implementację ekoinnowacji, ze szczególnym uwzględnieniem czynników hamujących ekoinnowacyjność. Rozważania teoretyczne poparto badaniami przeprowadzonymi wśród podmiotów gospodarczych działających w branży papierniczej w Polsce.

Słowa kluczowe: ekoinnowacja; czynniki warunkujące ekoinnowacyjność przedsiębiorstw. 